\title{
AN INVESTIGATION OVER POPULATION INCREASE IN URBAN AREAS AND EMPLOYMENT PROSPECTS IN ALBANIA
}

\author{
Mario Çurçija ${ }^{1}$ \\ Emirjeta Bejleri ${ }^{2}$ \\ ${ }^{1}$ Faculty of Economy \\ University of Shkoder, Albania \\ mario.curcija@unishk.edu.al \\ ${ }^{2}$ Faculty of Economy \\ University of Shkoder, Albania \\ emirjeta.bejleri@unishk.edu.al
}

\begin{abstract}
Migratory movements as individual or collective relocation from a place of origin to a place of destination represent a milestone in a person's life because it implies withdraw from two important places in a person's life: residence and work.

The phenomenon of migration affects demographics of the areas involve: shrinking populations in areas of origin and increasing in destination areas. Given that the causes of migration may be different, in this paper we focus on factors related to job opportunity as determinants of the decision to migrate. In this paper, our aim is to evaluate the relationship between the number of the population residents in a district and the job opportunities in that district in Albania. To perform this analysis, we use quantitative methods: the logit and the multinomial logit regression models based on a dataset of labor force survey for the period 2007-2013 in Albania. In this research we found a positive correlation between the increase in the number of residents in a district and job opportunities in activities different from agriculture, and, in particular the positive effect on job opportunities is higher than the average for women who have attained general education secondary school.
\end{abstract}

Keywords: job opportunities, demographic trend, transitional economies, Albania

JEL Classification: J10, J20, J61,

\section{Introduction}

Job opportunities are a major cause in internal migration. The process of Albania's political transition from a communist system with a centralized economy toward a market economy system, among other things, led to the deindustrialization and restructuring of the economy, which in turn led to a shift of the labor force from the secondary to tertiary sector of services. Such political and economic changes were followed by demographic changes. Unemployment is high in Albania, but it is unevenly distributed in the territory, given that internal areas suffer from economic depression, lack of job opportunities and higher unemployment than western areas, therefore emigration and the consequent depopulation is more pronounced in these areas. 


\section{Literature review}

According to a Marxist view, the city develops as an instrument of the industrial process. But while the quota of the surplus value that is created and realized by the industrial sector starts to decrease, the part of the surplus value created and realized in the city by the second circuit of capital, produced by estate speculation, increases and supersedes the first circuit of capital (Lefebrve, 1974). This causes that the wealth concentrated in a specific urban space determines the creation of a series of relationships that focus the attention of economic operators towards the city.

According to spatial analysis, the explanation for the development and growth of cities in the globalization era is based on the network paradigm (Pain, Van Hamme, Vinciguerra, \& David, 2016) in the sense that in our time globalization requires a great deal of integration and fast communication and participation. The participation of the city in the connectivity networks determines the economic success of the city. The most successful cities and areas are connected and integrated cities in the global economy, because the key activities of capitalism - high levels of innovation and technology - are realizes exactly in globalized urban centers (Scott, 2001). Strategic advantages, dissemination of information, knowledge and know-how, ease of communication and transportation favor the concentration of firms' businesses into one economic cluster (Porter, 1995), (Porter, Clusters and the New Economics of Competitiveness, 1998). Globalization goes along with and the centralization of strategic functions and global cities have comparative advantages for being at the center of the agglomeration of functions process (Sassen, 1994) (Sassen, The Global City: New York, London, Tokyo, 1991).

Cities and areas that, for one reason or another, possess a competitive advantage over other cities, in the freemarket system tend to increase the distance and deepen the advantage, because a small advantage attracts new businesses which in turn enlarge the market dimension, and, vice versa by increasing the demand which, according to Keynesian logic, leads to the growth of supply and the attraction of other new businesses in what (Myrdal, 1957) calls circular causation. The same circular causation may have the opposite effect as a vicious circle. It happens when the withdrawal of the state from some public services leads to a deterioration of the quality of life and therefore the residents that seek for better living conditions so decide to leave, but then this population shrink itself does not justify the presence of some other public services which are further reduced by dragging the system in a kind of vicious circle.

Production tends to focus where there is a broad market, but on the other hand, according to a Keynesian description of multiplicative effects, the market will be wide where the production enterprises will concentrate (Hirschman, 1958) (Arthur, 1989). A large market implies higher productivity and higher specialization and attracts people with knowledge, higher education, skilled professional, i.e., human capital who have better job opportunities and higher incomes (Schultz, 1961) (Becker, 1994). According to (Krugman, 1991) a country itself can differentiate its development into an industrialized "core" because of the advantages in transportation costs, economies of scale, and the share of manufacturing in national income and an agricultural "periphery."

\section{The case of Albania}

Until 1990 free movement in Albania was restricted by the communist regime which aimed at achieving economic self-sufficiency, egalitarianism, erasing inequalities at every level, planning every aspect of economic life including work and residence. The planned urbanization caused that the population growth of major cities during the period 1945 - 1989 was half of the country's population average growth (Kopliku, 2016). The cancellation of the overwhelming boundaries in 1991 caused massive internal migration from hinterland and rural areas towards urban areas.

This transformation is similar to the processes that took place in the western countries during the 1980s. Unlike jobs in the manufacturing sector which can concentrate in both large and small centers, the job opportunities in the service tertiary sector are generally located in urban enclaves where the best talent and creativity are concentrated (Porter E. , 2017). The definition ${ }^{1}$ of "transition" as an intermediate phase of transition from an old equilibrium towards a new equilibrium while conserving some features of the old structures, in the case of former

\footnotetext{
${ }^{1}$ Enciclopedia Italiana di Scienze, Lettere ed Arti - Treccani
} 
communist countries has had a more radical meaning than merely transition; it was as a shock that not merely evolved but had destructive consequences for the production systems (De Mel, McKenzie, \& Woodruff, 2011).

First of all, it is necessary to define the terminology used in this paper: resident population is defined as all persons who reside or intend to reside in the country for at least 12 months, regardless of their nationality ${ }^{2}$. The administrative units, which consist of residential areas used in this work is the district, which in the Republic of Albania is a territorial administrative unit in accordance with Law no. 8652, data. 31.07.2000:

The district is a second-level local government unit; the district represents an administrative-territorial unit, composed of several communes and municipalities with geographical, traditional, economic, social ties and common interests; The district boundaries correspond to the boundaries of the communes and municipalities that comprise it. The district center is located in one of the municipalities included in it. Territorial extension, name and district center are determined by the law. Albania has 12 districts. Their territory is defined by law.

\section{Purpose of the research}

The purpose of this paper is to check the existence of a relationship between the number of residents in an area and the possibilities of finding a job in that area.

Given that in the era of information technology the service sector is pivotal for the economy, we predict that as the service sector thrives in clusters in urban areas then job opportunities will be higher where the resident population is higher.

Another prediction we propose is based on the finding that, since that service sector jobs are largely based on skills, knowledge, high intellectual engagement and less physical performance than in the secondary manufacturing sector, then we expect that the positive effect of the growth of the population resident on job opportunities in an area will be comparatively higher for women with higher education.

\section{Methodology}

In order to test the hypotheses that population growth in an area is associated with increased job opportunities that area, and, in particular women who have achieved a solid formal education, we use two testing methods: logit model and multinomial logit model.

For the first hypothesis we use the logit model that is a regression model where the outcome, the dependent variable is a dichotomous variable which can have only two nominal categories $(1 ; 0)$, while the dependent variable is a continuous variable. In order to define the logit model, we use the cumulative distribution function of a standard normal random variable (Greene, 2011)

$$
\operatorname{Pr}\left(Y_{i t}=1 \mid X_{i t}\right)=\Phi\left(X_{i t} \beta\right)
$$

where Pr represents the probability that the outcome of interest $Y_{i t}$ (the status of a person resident in the district $i$ at the time $t$ ) is employed $=1$ or unemployed/inactive $=0, \Phi$ the cumulative distribution function of the explanatory variable $X_{i t}$, which is the population resident in the district $i$ at the time $t$ where $\mathrm{i}=$ (district of Berat, Dibër, Durrës, Elbasan, Fier, Gjirokastër, Korçë, Kukës, Lezhë, Shkodër, Tiranë, Vlorë) in the year $t=(2007$, 2008, 2009, 2010, 2011, 2012, 2013) $)^{3}$.

So, if the probability is higher than $50 \%$ than we assume that $Y_{i t}=1$ and if the model predicts significantly correctly, meaning that the percentage of correctly predicted responses is significantly higher than $60 \%-65 \%$,

\footnotetext{
${ }^{2}$ Instat Albania | Popullsia

${ }^{3}$ Source: Instat Albania | Popullsia
} 
ISSN 2661-2666 (Online) International Scientific Journal Monte (ISJM) DOI: 10.33807/monte.202004669 Volume 3 No. 1 (2020): April

than we may consider the model as valid. As long as the model is valid, then we can consider the average marginal effect of the explanatory variable on the probability that the outcome of interest is $1=$ employed.

Our sources of information are the quarterly labor force survey (LFS) for the period 2007-2013 in Albania ${ }^{4}$.

According to LFS, 40\% of the employees work in the agricultural sector (Instat Albania, 2019). Since that agricultural employment in low-income countries mainly takes the form of subsistence agriculture, we decided to exclude from the analysis for the first hypothesis the employees in the agriculture sector; therefore, we will refer to the employees in the non-agricultural private sector.

For the second hypothesis, we use the multinomial logit regression model which is an extension of the logit model where the response variable has more than two categories. One category, usually the most frequent, is designed as the reference, base category and the logit regression measures the probability of membership in other categories compared to the probability of membership in the base category depending on changes in the dependent variable. In our case the categories are: 1 - Employed No school, 2 - Employed Primary school, 3 - Employed school classes V-IX, 4 - Employed Upper secondary - vocational 2-3 years, 5 - Employed Upper secondary vocational 4-5 years, 6 - Employed Upper Secondary - general, 7 - Employed Tertiary / University, 8 - Employed Post university / Master resident in the district $i$ at the time $t$. The explanatory variable $X_{i t}$ is the population resident in the district $i$ at the time $t$.

\section{Analysis and Results}

The table below provides descriptive statistics for all variables used in the estimations.

Table 1. Summary Statistics H1

\begin{tabular}{cccccc}
\hline Variable & Obs & Mean Std. & Dev. & Min & Max \\
\hline District & 52281 & 6.738815 & 3.811573 & 1 & 12 \\
\hline District_Popul & 52281 & 205.2261 & 177.5034 & 28.3765 & 552.9084 \\
\hline Labour_Status & 52281 & 0.3267726 & 0.4690378 & 0 & 1 \\
\hline
\end{tabular}

Note: The district population in thousand; agriculture sector excluded

Source: own elaborations

The results of the logit test are presented in Table 2. Logit test H1. There was a significant positive correlation (pvalue $<0.01$, coef. $=0.001$ ) between increasing in the population of the district and job opportunities in the nonagricultural private sector. The model is valid as it correctly predicts $67 \%$ of the responses.

Table 2. Logit test $\mathrm{H1}$

\begin{tabular}{ccccccc}
\hline Labour_Status & Coef. & $\begin{array}{l}\text { Std. } \\
\text { Err. }\end{array}$ & $\mathbf{z}$ & $\mathbf{P}>\mathbf{z}$ & {$[\mathbf{9 5 \%}$ Conf. } & Interval] \\
\hline District Popul. & 0.001 & 0.000 & 15.770 & 0.000 & 0.001 & 0.001 \\
\hline _cons & -0.893 & 0.014 & -61.840 & 0.000 & -0.922 & -0.865 \\
\hline
\end{tabular}

\footnotetext{
${ }^{4}$ Source: Instat Albania | Labor Market. Micro data
} 
ISSN 2661-2666 (Online) International Scientific Journal Monte (ISJM) DOI: 10.33807/monte.202004669 Volume 3 No. 1 (2020): April

As far as the model is valid, then we can measure the average marginal effect (Table 3. Average marginal effect). In this case, the average marginal effect of the district's population increases by 1,000 units on the probability of the status "employed" in the non-agricultural private sector is $+0.02 \%$.

Table 3. Average marginal effect

\begin{tabular}{lcccccc}
\hline \multicolumn{3}{c}{ Delta-method } & & & & \\
& dy/dx & Std. Err. & $\mathbf{z}$ & $\mathbf{P}>\mathbf{z}$ & $\begin{array}{c}{[\mathbf{9 5 \%}} \\
\text { Conf. }\end{array}$ & Interval $]$ \\
& & & & & & \\
\hline District Popul. & 0.0002 & 0.0000 & 15.9100 & 0.0000 & 0.0002 & 0.0002 \\
\hline
\end{tabular}

The table below shows summary statistics for the multinomial logit tests by educational level grouped by gender.

Table 4. multinomial logit and average marginal effect by gender

\begin{tabular}{|c|c|c|c|c|c|}
\hline Gender & Edu. Level & Coef. Std. Err. & $\mathbf{P}>\mathbf{Z}$ & $d y / d x$ & $\mathbf{P}>\mathbf{Z}$ \\
\hline Male & 1- No school & .0004019 .0004357 & 0.356 & -0.00000182 & 0.571 \\
\hline Female & 1- No school & $-.0013532 \quad .0006017$ & 0.025 & -0.0000164 & 0 \\
\hline Male & 2 - Primary & $.0002912 \quad .00019$ & 0.125 & -0.0000164 & 0.044 \\
\hline Female & 2 - Primary & $.0003436 \quad .0002036$ & 0.091 & -0.0000155 & 0.101 \\
\hline Male & 3 - 8/9-years school & (base outcome) & & -0.00029 & -0.0000159 \\
\hline Female & 3 - 8/9-years school & (base outcome) & & -0.00035 & -0.000294 \\
\hline Male & 4 - Up. Sec. Vocation 2-3 yrs & .0011822 .0001881 & 0 & -0.000354 & 0.002 \\
\hline Female & 4 - Up. Sec. Vocation 2-3 yrs & $.0011586 \quad .0002963$ & 0 & 0.0000198 & 0.077 \\
\hline Male & 4 - Up. Sec. Vocation 4-5 yrs & $.0010869 \quad .0001065$ & 0 & 0.00000968 & 0 \\
\hline Female & 4 - Up. Sec. Vocation 4-5 yrs & $.0008829 \quad .0001433$ & 0 & 0.0000668 & 0.059 \\
\hline Male & 6 - Upper Second. - general & $.0010184 \quad .0000962$ & 0 & 0.0000238 & 0 \\
\hline Female & 6 - Upper Second. - general & $.0015568 \quad .0001134$ & 0 & 0.0000777 & 0 \\
\hline Male & 7 - Tertiary / University & $.0022542 \quad .0001267$ & 0 & 0.0001494 & 0 \\
\hline Female & 7 - Tertiary / University & $.0024771 \quad .0001332$ & 0 & 0.0001231 & 0 \\
\hline
\end{tabular}


ISSN 2661-2666 (Online) International Scientific Journal Monte (ISJM) DOI: 10.33807/monte.202004669 Volume 3 No. 1 (2020): April

\begin{tabular}{llllllll} 
Male & 8 - Post university / Master & .0019608 & .0007004 & 0.005 & 0.0001615 & 0.051 \\
\hline Female & 8 - Post university / Master & .0030982 & .000668 & 0 & 0.00000273 & 0 \\
\hline
\end{tabular}

The base category of the employed by educational level, i.e., the largest category, are the employed who have attained the 8/9-years school education level.

The effect of district population increase does not appear to have a significant effect (pvalue> 5\%) on the employed persons that have attained only primary school or no school at all.

Higher formal education increases the probability of job opportunities for people who have attained a higher education level than 8/9-years school; the more the district's population increases, the lower is the percentage of the employees who have attained only 8/9-years of education.

The district's population increase of 1,000 units has a negative marginal effect on the employment of people with an 8/9-year school education level; for women the negative marginal effect is higher $(-0.04 \%)$ than for men ($0.03 \%)$. Also, population growth has a higher effect in amplitude for women, this time a positive effect, for women who have attained upper secondary general education: for women it is $+0.008 \%$ while for men it is four times lower, $+0.002 \%$.

For the other educational levels, the marginal effect of population growth is higher for men than for women.

\section{Discussion}

Statistical analyzes confirm our expectations that population growth is associated with increased opportunities to find a job in the non-agricultural private sector. If this population growth is the effect of another cause such as proximity to markets, greater openness of urban areas to globalization, better geographical location, these are considerations that are not the object of study of this paper and may be evaluated as a topic in the future. Population growth appears to have a higher positive effect on women who have attained upper secondary general education than men who have attained the same education level.

Increasing job opportunities, on the other hand, also increase the population of the district, as we can easily imagine situations where people migrating toward a certain district tend to take with them their families. Also, districts where job opportunities are higher tending to attract the unemployed from economically depressed areas. In this case, the decline of unemployment in economically depressed areas is not the result of an increase of job opportunities but rather of job-seekers abandonment. Therefore, in interpreting the results we are careful not to present the relation of the number of resident populations - job opportunities as a unidirectional relationship, but as a dual process. 
ISSN 2661-2666 (Online) International Scientific Journal Monte (ISJM) DOI: 10.33807/monte.202004669 Volume 3 No. 1 (2020): April

\section{References}

Arthur, W. B. (1989). Competing Technologies, Increasing Returns, and Lock-In by Historical Events. The Economic Journal, Vol. 99, No. 394, 116-131.

Becker, G. (1994). Human Capital: A Theoretical and Empirical Analysis With Special Reference to Education. Chicago: The University of Chicago Press.

De Mel, S., McKenzie, D., \& Woodruff, C. (2011). Enterprise Recovery Following Natural. The Economic Journal, 64-91.

Greene, W. (2011). Econometric Analysis. New Jersey: Prentice Hall.

Hirschman, A. O. (1958). The Strategy of Economic Development. New Haven: Yale University Press.

Instat Albania. (2019, 12 12). Të dhëna administrative të tregut të punës. Tratto il giorno 01 12, 2020 da Instat Albania: http://www.instat.gov.al/al/temat/tregu-i-punës-dhe-arsimi/të-dhëna-administrative-të-treguttë-punës/\#tab2

Instituti i Statistikave . (2014). Nje klasifikim i ri urban-rural i popullsise shqiptare. Tirane: Pegi.

Kopliku, B. (2016). Migrimi i Brendshem ne Rajonin e Shkodres gjate viteve 1945 - 1990. Buletini Shkencor Universiteti i Shkodres, Seria Shkencat Shoqerore.

Krugman, P. (1991). Increasing Returns and Economic Geography. Journal of Political Economy,

Lefebrve, H. (1974). La production de l'espace. Paris: Éditions Anthropos.

Lefebvre, H. (2018). La produzione dello spazio. Pgreco.

Myrdal, G. (1957). Economic theory and under-developed regions. London: Duckworth.

Open Data Albania. (2013). Popullsia sipas qarqeve, densiteti dhe urbanizimi 2001-2013. Tratto il giorno 0110 , 2020 da open.data.al: http://open.data.al/sq/lajme/lajm/lang/sq/id/716/Popullsia-sipas-qarqeve-densiteti-dhe-urbanizimi-2001-2013

Pain, K., Van Hamme, G., Vinciguerra, S., \& David, Q. (2016). Global networks, cities and economic performance: Observations from an analysis of cities in Europe and the US. Urban Studies, 53 (6), $1137-1161$.

Petrakos, G. C. (1997). Industrial Structure and Change in the European Union: Comparative Analysis and Implications for Transition Economies. Eastern European Economics, 41-63.

Popescu, C. (2014). Deindustralization and Urban Shkrinkage in Romania. What lessons for the spatial policy? Transylvanian Review of Administrative Sciences, 42, 181-202.

Porter, E. (2017, October 10). Why Big Cities Thrive, and Smaller Ones Are Being Left Behind. Tratto il giorno January 06, 2020 da New York Times: https://www.nytimes.com/2017/10/10/business/economy/bigcities.html

Porter, M. (1995). Clusters and the New Economics of Competitiveness. Harvard Business Review, 77-90.

Porter, M. (1995). The Competitive Advantage of the Inner City. Harvard Business Review, MayJune,, 53-71.

Porter, M. (1998). Clusters and the New Economics of Competitiveness. Harvard Business Review, 
ISSN 2661-2666 (Online) International Scientific Journal Monte (ISJM) DOI: 10.33807/monte.202004669 Volume 3 No. 1 (2020): April

Sassen, S. (1991). The Global City: New York, London, Tokyo. Princeton NJ: Princeton University Sassen, S. (1994). Cities in a World Economy. London : Pine Forge Press.

Schultz, T. W. (1961). Investment in Human Capital. The American Economic Review, 51(1), 1-17.

Scott, A. J. (2001). Globalization and the rise of city- regions. European Planning Studies, 9(7), 813-826. 